\title{
The Quranic Conditionally Pharyngealized Sounds: An Optimality Theory Perspective
}

\author{
Fatima Abdullah Almousa \\ Department of Linguistics and Translation Studies \\ College of Languages and Translation \\ King Saud University, Riyadh, Kingdom of Saudi Arabia \\ Corresponding Author: F.AbdullahAlmousa@gmail.com \\ Faisal M. Al-Mohanna \\ Department of Linguistics and Translation Studies \\ College of Languages and Translation \\ King Saud University, Riyadh, Kingdom of Saudi Arabia
}

Received: 6/12/2021

Accepted: 8/3/2021

Published: 8/25/2021

\begin{abstract}
This paper investigates the Qur'ānic conditionally pharyngealized sounds which are $/ \mathrm{r}^{\mathrm{f}} /, / 1 /$, and /a:/. The Qur'ānic $/ \mathrm{r}^{\complement} /$ sound undergoes a depharyngealization process. The Qur'ānic /1/ sound in the word Allah, on the other hand, exhibits pharyngealization, as does the Qur'ānic /a:/ sound. Hence, the study aims to provide a thorough examination of these phonological processes within the Optimality Theory framework. The study also attempts to answer the following questions: (1) What constraints are considered to account for the pharyngealization of the Qur'ānic sounds /1/ and /a:/ and the depharyngealization of the Qur'ānic sound $/ \mathrm{r}^{\mathrm{S}} /$ in the Holy Qur'ân? and (2) How does the grammar rank these constraints to achieve the pharyngealization of the Qur'ānic sounds /1/ and /a:/ and the depharyngealization of the Qur'ānic sound $/ \mathrm{r}^{\mathrm{S}} /$ in the Holy Qur'ān? Both questions have been fully addressed. In addition, this study has proven that the pharyngealized $/ \mathrm{r}^{\mathrm{s}} /$ is the underlying representation of the Qur'ānic alveolar trill sound. This was achieved by demonstrating $\left[\mathrm{r}^{\mathrm{S}}\right]$ and $[\mathrm{r}]$ allophones environments. Also, the study has shown that the pharyngealized $\left[1^{\mathrm{S}}\right]$ and the non-pharyngealized [1] in the word Allah are comparable to the dark /l/ in English. The Qur'anic /a:/ acquires the [RTR] feature from the preceding pharyngealized sound where it spreads its [RTR] feature rightward to the /a:/. The study concludes that the constraint-based analysis could provide a plausible accounted for examining these phonological processes in the Holy Qur'ān.
\end{abstract}

Keywords: Pharyngealization, Depharyngealization, Optimality Theory, The Holy Qur'ān, Tajweed

Cite as: Almousa, F.A.,\& Al-Mohanna, F.M. (2021). The Quranic Conditionally Pharyngealized Sounds: An Optimality Theory Perspective. Arab World English Journal for Translation \& Literary Studies 5 (3) 125-150. DOI: http://dx.doi.org/10.24093/awejtls/vol5no3.10 


\section{Introduction}

Classical Arabic is the language of the Holy Qur'ān, the fundamental book of Islam, which was revealed by Allah to his last Prophet, Muhammad (may the peace and blessings of Allah be upon him) for the true guidance of humanity. The Holy Qur'ān can be defined as Allah's words transmitted to the Prophet by the Angel Gabriel (Von Denffer, 1983) In Islam, Muslims are commanded to read the Qur'ān, recite it, and listen to its words as an act of worshipping Allah. In the Qu'rān, Allah says, "Recite the Qur'ān with measure recitation (warattili alqurana tartila)" (The Qu'rān 73:4). This indicates that the Qur'ān should be recited with Tajweed. Tajweed linguistically means 'proficiency' or 'doing something well'. When applied to the Quran, it implies the proper pronunciation, and articulation of each letter from its correct articulation point (Elhassan, 2015).

Tajweed involves a set of phonological rules that regulate how the Qur'ān should be recited. One of the many phonological processes of Tajweed is the pharyngealization of sounds. Pharyngealization, traditionally known as emphasis, is a secondary articulation involving the constriction of the pharynx (Almasri \& Jongman, 2004). Classical treatises on Arabic have characterized pharyngealization as Tafkhìm (thickening). In Qur'ānic recitations, the phonemes /1/and /a:/ exhibit phonetic characteristics similar to those of the primary pharyngealized phonemes

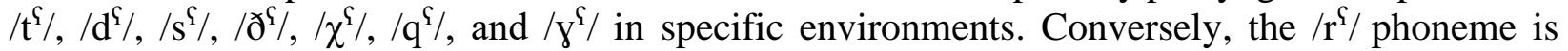
depharyngealized. These three phonemes are the focus of the present work, which follows Hafsian Asim's reading.

This study addresses the conditionally pharyngealized sounds in the Holy Qur'ān within the OT framework. The Qur'ānic / $\mathrm{r}^{\mathrm{S}} /$ sound shows a phonological process known as depharyngealization. In contrast, the Qur'ānic /1/ sound in the word Allah is pharyngealized in specific environments, as does the Qur'ānic /a:/ sound. The Qur'ānic /a:/ acquires a pharyngealized feature because of the preceding pharyngealized sound's influence.

\section{Research questions}

1. What constraints are considered to account for the $/ \mathrm{r}^{\mathrm{S}} /$ depharyngealization, and the $/ \mathrm{l} /$ and /a:/ pharyngealization in the Holy Qur'ān?

2. How does the grammar rank these constraints to achieve the $/ \mathrm{r}^{\mathrm{f}} /$ depharyngealization, and the /1/ and /a:/ pharyngealization in the Holy Qur'ān?

The paper is organized as follows: section two is the literature review, which is organized as follows: Arabic emphatics and pharyngealization, the Qur'ānic pharyngealized sounds, the phonological status of /l/ in Arabic, the phonological status of /r/ in Arabic, the influence of Arabic emphatics, and Arabic emphatic sounds and the phonological theory. The research framework is established in section three. Section four provides an Optimality Theory (OT)-based analysis with three subsections: the Qur'ānic /r̊/, the Qur'ānic /l/, and the Qur'ānic /a:/. Finally, the conclusion is presented in section five.

Arab World English Journal for Translation \& Literary Studies 


\section{Literature Review}

\section{Arabic Emphatics and Pharyngealization}

Aldamen (2013) defined emphasis as a phonetic and phonemic feature of all Semitic languages, including Arabic. Many linguists have attempted to define emphasis, Jongman, Herd, Al-Masri, Sereno, and Combest (2011) among them. They stated that the term emphasis "refers to consonants produced with a secondary constriction in the posterior vocal tract and a primary constriction typically in the dental/alveolar region" (p. 85). Conversely, Davis (1995) defined emphasis, which corresponds, as he posits, to pharyngealization, as the phenomenon of producing sounds, "with a primary articulation at the dental/alveolar region and with a secondary articulation that involves the constriction of the upper pharynx" (p. 465). Norlin (1987) pointed out that Arab grammarians have traditionally regarded emphasis as an inherent feature of emphatic consonants that form an additional series of voiceless, voiced stops and sibilants that phonemically differ from their plain counterparts. These sounds are represented in the Arabic alphabet by separate graphemes. Additionally, Alwabari (2020) demonstrated that emphasis is a contrastive secondary posterior constriction. The plain $/ \mathrm{t} d \partial \mathrm{s} /$ contrasts with emphatic $/ \mathrm{t}^{\mathrm{\varsigma}} /, / \mathrm{d}^{\mathrm{\varsigma}} /, / \mathrm{\delta}^{\mathrm{s}} /$, and $/ \mathrm{s}^{\mathrm{s}} /$ in most Arabic varieties, while other dental and alveolar consonants, such as /n/, /z/, and /l/, have no emphatic counterparts.

Alwabari (2020) stated that there is continuous disagreement regarding the exact location and main articulator responsible for this posterior constriction. According to Kahn (1975) velarization, uvularization, pharyngealization, retraction, strong articulation, resonance, and heaviness can all be used to describe the articulatory configuration of emphatic sounds. A physiological and acoustic investigation of pharyngeal and emphatic consonants was conducted by Laufer and Baer (1988) in both Arabic and Hebrew. They found that emphatic sounds are realized as pharyngealized, having a secondary articulation in the lower part of the pharynx. Al-Tamimi, Alzoubi, and Tarawnah (2009) also aimed to classify the nature of emphatic consonants and the articulatory features accompanying their production across Jordanian speakers in a videofluoroscopic experiment. Their findings revealed that emphatic sounds are produced as pharyngealized sounds by the tongue root retracting into the oropharynx, the hyoid bone elevating, and the larynx raising. One study by Alwabari (2020) addressed articulatory realizations of emphasis as pharyngealization or uvularization. To accomplish this, ultrasound data was collected of native speakers of Eastern Peninsular Arabic articulating a set of consonants in both emphatic and plain contexts. The findings showed that the emphatics $/ \mathrm{t}^{\mathrm{S}} /$ and $/ \mathrm{s}^{\mathrm{S}} /$ are articulated with pharyngealization by retracting the tongue root toward the back of the pharyngeal wall and, consequently, depressing and flattening the tongue body and dorsum.

On the other hand, McCarthy (1994) indicated that emphatic consonants in Arabic are similar to the uvular gutturals $/ \mathrm{X} /$ and $/ \mathrm{\gamma} /$ in terms of "constriction in the upper pharynx." Thus, he argued that pharyngealized sounds should be referred to as uvularized. Jongman et al. (2011) supported McCarthy's view by replacing the term "emphasis" with "uvulariztion" in their study on the acoustical properties of emphasis in Urban Jordanian Arabic. However, Sibawayhi, an Arabic grammarian who lived in the eighth century, realized emphasis as velarization. He believed that emphatics are a secondary articulation, and the back of the tongue is constricted against the velum 
that it is realized as velarization. Several scholars had accepted his theory without question, and emphasis has therefore become synonymous with velarization (as cited in Laufer \& Baer, 1988).

Druel (2006) pointed out that emphasis in traditional Arabic corresponds to the term Tafkhim /tafxi:m/ and covers a wide range of articulatory and acoustic effects. Lehn (1963) mentioned that Arab grammarians have identified emphatic sounds as / itbaq/, "spreading and raising of the tongue, /PistiYla?/, "elevation of the dorsum," and /tafxi:m/, "thickness, heaviness."

According to Card (1983), a speech sound with a primary articulation in the anterior vocal tract and a secondary articulation in which the back of the tongue moves toward the pharyngeal wall is referred to as pharyngealization (as cited in Binasfour, 2018). Alhammad (2014) emphasized the importance of using the word "pharyngealized" rather than "pharyngeal" to describe consonants with an emphasis feature. While the two terms sound similar, the associated location of articulation differs. Pharyngeal refers to consonants, such as the voiced pharyngeal fricative / $/ \mathrm{G} /$ and the voiceless pharyngeal fricative $/ \hbar /$, where the pharynx is the primary articulation. On the other hand, pharyngealized refers to consonants produced with the pharynx as a secondary articulation. According to Hoberman (1985), there should be an intimate relationship between pharyngeals and pharyngealization. Arabic is the best-known language that has both, and they only interact sporadically.

\section{The Qur'ānic Pharyngealized Sounds}

Alsurf (2013) has examined the emphatic sounds in the Holy Qur'ân; he indicated that there have been numerous, inadequate accounts of the emphatic sounds therein. As a result, he has investigated the phonetic identity of these sounds. Alsurf acoustic and articulatory studies have revealed that Qur'annic emphatic sounds should be referred to as pharyngealized rather than velarized or uvularized. The majority of the classical treatises have defined Qur'ānic pharyngealization as a state of thickening that covers the sounds, causing an echo in the mouth when pronouncing them.

According to Alsurf (2013), in Qur'ān recitation, some sounds are pharyngealized and depharyngealized in specific environments. Examples on these are the Qur'ānic /r/, /l/, and /a:/ sounds. The Qur'ānic/r/ sound is maintained as a pharyngealized sound except when the adjacent sounds influence it. Thus, the Qur'ānic / $\mathrm{r} /$ sound has two allophones, pharyngealized and depharyngealized.

Alsurf (2013) has classified the pharyngealized and the non-pharyngealized /// sounds in the holy Quran as phonemes rather than allophones. He agreed with Ferguson's (1956) observation that the emphatic /1/ must be viewed as an independent phoneme in Classical Arabic and most modern dialects. Ferguson (1956) has argued that the emphatic / 1 / must be regarded as an independent phoneme in Classical Arabic and in most modern dialects. According to Ferguson, /l/ must be regarded as a separate phoneme in the word Allah or be treated as entirely outside the language's phonological system. He demonstrated that minimal pairs can be found involving the word Allah and another word of similar phonological shape in other Arabic varieties; the Syrian 
Arabic example of [?alla] 'he told her' and [?llah] 'Allah' comes to mind. However, Ferguson mentioned that these pairs are not reliable, as the first word may be pronounced [?allha] in slow speech. A convincing example is seen in most dialects, including Syrian: pairs like wall a "by Allah" and walla "he appointed" (as a guardian). Alsurf (2013) stated, "what is missing in the treatment of Ferguson here is that this sound is sometimes predictable in Arabic, but not in the same sense as an allophone conditioned by its surrounding phonetic context." (p.110). There is a rule that occurs in Qur'anic recitation in which this sound is pharyngealized in the word Allah and pronounced like the English dark /l/. However, Alsurf regarded the alveolar lateral pharyngealized and the alveolar lateral non-pharyngealized two different phonemes.

Amer (2016), on the other hand, considered the $\left[\left[^{5}\right]\right.$ mufakhama and the [1] muraqaqah in the name of Allah "Lamul-Jalalah," as allophones of the phoneme /1/. she demonstrated that the $/ 1 /$ in the name of Allah "Lamul-Jalalah," can be articulated with the mouth open wide and the tongue assuming a spoon-like shape. Also, it can be articulated with a mouth not open wide and in a neutral tongue motion. She also pointed out that the vocal variations of Lamul-Jalalah are universal and that the phonetics of the Qur'an are not unique in this regard. Thus, Amer (2016) proposed that the pharyngealized $\left[{ }^{\mathrm{S}}\right]$ in the word Allah is comparable to the dark [1] in English while the nonpharyngealized [1] is similar to the clear [1]. Nevertheless, in English, the dark [1] pharyngealized [1] is similar to the clear [1]. Nevertheless, in English, the dark [1] occurs after consonants and in final positions while the clear [1] occurs in initial and medial positions (Amer, 2001). The dark [1], or the pharyngealized $\left[{ }^{\complement}\right]$, and clear [1] or non-pharyngealized [1], may be classified by the presence or absence of a postdorsal constriction in the upper pharyngeal region and of considerable predorsum lowering, respectively (Recasens \& Espinosa 2005). This shows the resemblances of the articulatory properties of the dark [1] and the pharyngealized $\left[1^{\complement}\right]$. According to Halle \& Mohanan (1985), the two /l/s are distinct entities. The dark variant is deriving from its clear counterpart by acquiring a feature [+back]. This study agrees with Amer's (2016) observations, given that the pharyngealized $\left[1^{\complement}\right]$ allophone and the non-pharyngealized [1] allophone in the word Allah do not have a contrasting meaning in the Holy Qur'an.

Alsurf pointed out that the Qur'ānic vowel /a:/ is pharyngealized when other pharyngealized sounds precede it. It cannot be characterized as a pharyngealized or depharyngealized sound as it does not inherently have either feature. Rather, it reflects the preceding sound's effect. The Qur'ānic /a:/ pharyngealization in Qur'ān recitation is an open back, rounded vowel. However, rounding is not a distinctive feature of Qur'ānic pharyngealization sounds. Alsurf reported," It is perceptually obvious that /a:/ is the most salient vowel sound to study because pharyngealisation is easily perceived in this context" (p.111).

In summary, the previous two subsections have reviewed the Arabic emphasis and the Qur'ānic emphatic sounds. In the first subsection, the articulatory studies of the Arabic emphatic consonants in the literature have been discussed. Also, the definition of pharyngealization has been provided, and the difference between pharyngeal and pharyngealized has been clarified. The second subsection clarified that the emphatic sounds in the Holy Qur'ān are referred to as pharyngealized sounds and discussed the conditionally pharyngealized sounds as well. 
This study follows Alsurf (2013) in the belief that the emphatic sounds in the Holy Qur'an should be regarded as pharyngealized sounds. This is because Alsurf revealed in his articulatory study that Qur'anic emphatics are articulated with pharyngealization. This is reliable evidence that Qur'anic emphatic sounds are pharyngealized. Therefore, this paper adopts the term "pharyngealization" to refer to the Qur'anic emphatic sounds.

\section{The Phonological Status of /r/ in Arabic}

Oueslati (2017) described the Arabic / $\mathrm{r}$ / as "a flap produced by striking the tip of the tongue against the roof of the mouth"(p.71). Oueslati mentioned that Sibawayhi has characterized the rphone as vibrant (repetitious) and occlusive; vibrant refers to a quick vibrating movement when the tip of the tongue touches the upper gum. O'Leary (1923) has indicated that the Arabic / $\mathrm{r} /$ is typically allied with emphatic consonants. Nevertheless, its influence on neighboring segments seems to be more restricted, and it alternates with a non-emphatic [r] (as cited in Youssef, 2019).

In the spoken Arabic varieties, the /r/ phones are in contrastive distribution, while others are contextually conditioned or free variants. Youssef (2019) has investigated the underlying /r/ phoneme in the spoken varieties of Arabic; he illustrated four major patterns based on the nature and number of Rs found in Arabic dialects.

According to Youssef, the existence of two contrastive phonemes, a plain /r/ phoneme and an emphatic $/ \mathrm{r}^{\mathrm{s}} /$ phoneme, are found in the Maghrebi dialects of North Africa, Egyptian dialects, and a few peripheral dialects spoken in Sub-Saharan Africa. For example, in Cairene Arabic, there are the contrasts [r $\mathrm{r}^{\mathrm{S}}$ fff] "shelf" vs. [raff] "it twitched." Additionally, in Moroccan Arabic, the $/ \mathrm{r}^{\mathrm{q}} /$ is emphatic, as in [da: $\mathrm{r}^{\mathrm{q}}$ ] "house", which contrasts with the non-emphatic /r/ [da:r] "he did."

On the other hand, in the Levantine dialects, the emphatic $/ \mathrm{r}^{\mathrm{s}} /$ has two allophones, the emphatic $\left[\mathrm{r}^{\mathrm{S}}\right]$ and the plain $[\mathrm{r}]$. The emphatic $/ \mathrm{r}^{\mathrm{S}} /$ is the underlyingly representation in the Levantine dialects. Youssef demonstrated that the main reason for considering the emphatic $/ \mathrm{r}^{\mathrm{f}} /$ as the underlying representation of the alveolar trill is that the plain $/ \mathrm{r} /$ is predictable. As a result, he claimed that it is reasonable to assert that a single emphatic /r/ phoneme de-emphasizes [r] in those specific contexts.Alternatively, in the Peninsular Arabic dialects and the Mesopotamian gilit-dialects of Iraq, the underlying form of the alveolar trill is the non-emphatic $/ r /$ phoneme with two allophones, the plain $[\mathrm{r}]$ and the emphatic $\left[\mathrm{r}^{\mathrm{C}}\right]$.

\section{The Influence of Arabic Emphatics}

Norlin (1987) illustrated that emphasis does not only involve emphatic consonants. It also affects adjacent vowel sounds. Emphasis is regarded as an inherent feature of consonants. This allows each vowel to have two allophones; one is emphatic and occurs when the vowel is preceded or followed by an emphatic consonant, and the other is a plain allophone, which occurs in other environments.

According to Davis (1995), in Arabic dialects, emphasis (i.e., pharyngealization) usually spreads to the neighboring sounds when an underlying emphatic occurs in a word. Norlin (1987) 
has revealed that the patterns of emphatics influence, e.g., whether the direction of emphatic spread is to the right or left, vary between dialects. Additionally, the spread range is also a distinguishing factor: syllabic, polysyllabic, or comprising whole words.

An acoustic study by Kalaldeh and Al-Shdaifat (2019) ai

med to investigate the influence of the voiced alveolar emphatic / $\mathrm{d}^{\mathrm{s}} /$ on the six monophthongs $/ \mathfrak{e}-\mathrm{I}-\mathrm{v}-\mathrm{a}:-\mathrm{i}:-\mathrm{u}: /$ in terms of vowel quality, vowel duration, and directionality of emphasis spread as produced by ten speakers from Jordan. The findings illustrated that the vowel quality of the low and central-back vowels are the ones most affected by / d $\%$. Furthermore, the vowel duration results reveal that the long vowels in the emphatic context did exhibit retraction, but to a lesser extent than short vowels.

The previous subsection has discussed the phonetic description of Arabic trill alveolar phonemes. The /r/ phoneme behaves differently in different Arabic dialects; some have considered the empathic and non-emphatic as separate phonemes. Others have regarded the emphatic $/ \mathrm{r} / \mathrm{as}$ the underlying form, and some others have considered the non-emphatic $/ \mathrm{r} /$ as the underlying representation. Examining the underlying form of alveolar trill in Arabic is essential in this paper. This is because it is relevant to the present analysis of the Qur'anic alveolar trill sound. Furthermore, the following subsection revealed that phonemes' emphasis may affect the adjacent vowel sounds, which is related to the current analysis of the Quranic pharyngealized /a:/ sound.

\section{Arabic Emphatic Sounds and the Phonological Theory}

Alsurf (2013) argued that the Arabic emphatic sounds need to be aligned with phonological theory. Sounds would be more phonologically unified if they could be grouped by one class or distinctive feature. McCarthy (1994) stated that "An adequate theory of distinctive phonological features must be able to characterize all and only the natural classes of sounds that recur in the phonological phenomena" (p. 191). A natural class is a phonological class of phonemes whose grouping can be explained in terms of phonetic factors that exclude all other phonemes (Mielke, 2004).

The Sound Pattern of English (SPE) feature system has distinguished the emphatic sounds from the non-emphatic sounds; the emphatics are [+low, +back] (Chomsky \& Hall 1968). According to Bin-Muqbil (2006), these tongue body specifications follow from the fact that the tongue body is actively involved in producing emphatics' secondary articulation. The SPE model assumes that emphatics are truly pharyngealized because their tongue body specifications are identical to pharyngeal sounds.

McCarthy (1994) noted that the specifications for [-anterior, -high] features classify gutturals differently from the other sounds based on these specifications. However, the specifications for [low, back] distinguish each of the three guttural classes, pharyngeal, laryngeal, and uvular, from each other. According to McCarthy (1994), there are some problematic parts of the feature specifications for guttural because the [-high] feature for the uvular class is inconsistent with the articulation of these sounds in Arabic; Arabic uvulas are produced with the raising of the tongue body. Additionally, the [+low, +back] featural specifications of the tongue body for pharyngeals 
is inaccurate because pharyngeals' articulation does not include the tongue body but rather the tongue root/epiglottis and the posterior pharyngeal wall. The body of the tongue is not in the back for pharyngeals in Arabic; it is actually in the front. Lastly, the assignment of [+low] feature to laryngeals is entirely inaccurate as the tongue body cannot be involved in laryngeal production. Therefore, McCarthy (1994) proposed [pharyngeal] as a feature that identifies a class of gutturals. All gutturals are articulated by constriction in the same vocal tract region, where the articulation of the sound is in the broad region from" the larynx to the oropharynx inclusive."

There are three articulators with access to this region: the larynx, the tongue root, and the tongue body. The [pharyngeal] feature also includes secondary articulation found in Arabic emphatic coronals, as they also have pharyngeal constriction. McCarthy claimed that emphatics are uvularized because of the acoustic similarity between emphatics and uvulars; he acknowledged the [dorsal] feature for uvulars and emphatics, as both are articulated with tongue dorsum retraction. However, he has indicated that the feature [dorsal] is redundant for emphatics and is not part of their underlying specification; rather, he referred emphatics to the place of articulation [pharyngeal]. Rose (1996) classified uvulas, pharyngeals, and emphatics by Tongue Root Retraction (RTR), which involves retracting the tongue root or constriction of the pharynx. Nonlaryngeal gutturals, however, are excluded from the set of RTR sounds.

This subsection highlights the natural phonological class known as the [pharyngal] and presents the RTR feature, contributing to the current analysis. In general, the literature review above has shown that acoustic and physiological studies have been conducted on the Quranic $/ \mathrm{r}^{\mathrm{f}} /, / 1 /$, and $/ \mathrm{a}$ :/ sounds; however, there is no theoretical research on these sounds. Therefore, the current research has come to fill in this missing gap in the literature. It aims to provide a detailed analysis of these phonological processes within the OT framework. It will add to the existing literature by shedding light on the processes within a constraint-based analysis.

\section{Research Framework}

This study adopts Optimality Theory (OT), which is based on the idea that surface forms of language reflect conflicts between competing demands or constraints. OT states that all constraints are part of universal grammar (UG); a constraint is a structural requirement which an output form may satisfy or violate. The less serious violations of a set of violable constraints allow a surface form to be "optimal." A constraint is only violated when a given form fails to meet its structural requirement. OT deals with two types of constraints, called markedness and faithfulness constraints. The markedness constraint requires that output forms meet some criterion of structural well-formedness, while the faithfulness constraint requires that outputs preserve the properties of their basic (lexical) forms. Constraints conflict when any grammars' output form must violate some constraints. Languages differ in their ranking of constraints, and different rankings are therefore the source of cross-linguistic variation. The rankings are based on a criterion of 'strict' dominance. When one constraint outranks another, the constraint with the higher rank has priority. Despite violations of the lower-ranked one, the violation must be minimal.

Arab World English Journal for Translation \& Literary Studies 
There are three components of OT grammar, lexicon, generator, and evaluator. The lexicon contains lexical representations or underlying forms that form the generator's input. The generator (Gen) then generates the output candidates for some input and submits them to the evaluator. The evaluator (Eval) is where the output candidates are evaluated in terms of ranked constraints, after which the optimal candidate is selected (Kager, 1999).

Ranking arguments are demonstrated with tableaux; this study adopts McCarthy's (2008) combination tableau. McCarthy (2008) states, "the combination tableau is the ideal instrument for constructing and presenting a ranking argument" (p.47). According to McCarthy, the combination tableau ensures that the first two requirements of a valid ranking, constraint conflicts and a winner, are met. The combination tableau is established by first constructing a violation tableau. The violation tableau has one row for each candidate being compared and one column for each constraint. The constraints are listed in the top row from highest-ranked to lowest-ranked. The candidates are listed in the first column. The index ( indicates the winner, and the cells containing the asterisks $(*)$ indicate information about constraint violations. W and $\mathrm{L}$ annotations are then added to the loser row. (W) denotes that the constraint favors the winning candidate, while (L) denotes that the constraint favors the losing candidate. The cells with $\mathrm{W}$ and L show that these constraints compete over the choice of the winner. For the winner to win, the constraint with the $\mathrm{W}$ must be higher than the one with the L.

\section{Optimality Theoretical Analysis of the Conditionally Pharyngealized Qur'ānic Sounds}

In Qur'ān recitation, seven sounds must be pharyngealized at all times. These sounds are $/ \mathrm{t}^{\mathrm{f}} /$, $/ \mathrm{d}^{\mathrm{\complement}} /, / \mathrm{s}^{\mathrm{\complement}} / / \mathrm{\delta}^{\mathrm{\complement}} /, / \mathrm{x}^{\mathrm{\complement}} /, / \mathrm{q}^{\mathrm{\complement}} /$, and $/ \mathrm{\gamma}^{\mathrm{\complement}} /$. On the other hand, there are three sounds that may depharyngealize, pharyngealize, or have acquired a pharyngealized feature in specific environments. These are the Qur'ānic / $\mathrm{r}^{\mathrm{s}} /, / 1 /$, and /a:/ sounds, respectively. This section offers an OT analysis of the conditionally pharyngealized sounds in Qur'ānic recitation.

The articulatory descriptions for the Qur'ānic vowels are presented first before moving to the analysis of the Qura'nic $/ \mathrm{r}^{\mathrm{Y}} /, / 1 /$, and /a:/ sounds. This is because vowel sounds contribute to the analysis of the depharyngealization of $/ \mathrm{r}^{\mathrm{s}} /$ and pharyngealization of $/ 1 /$. Gadoua (2000) describes the Qur'ānic vowels /a/ and /a:/ as low front vowels, /i/ and /i:/ as high front vowels, and /u/ and /u:/ as high back vowels. Al-Hashmi (2004) claimed that the Arabic vowels description is equivalent to the description of Qur'ānic vowels. This study regards the /a/ and /a:/ as low back vowels because /a/ and /a:/ have the same effect as /u/ and /u:/ in terms of the pharyngealization process. It is also necessary to know the secondary pharyngealization feature, which is the [RTR] feature proposed by Davis (1995). Furthermore, Archangeli and Pulleyblank (1994) have pointed out that there is a grounded path condition of Arabic pharyngealization that plays a significant role in the analysis. This grounded path condition manifests that the tongue body position in the articulation of a [front] or [-back] is antagonistic to the retraction of the tongue root Archangeli and Pulleyblank viewed this grounded path condition as "medium" (as cited in Davis, 1995). This grounded path condition is as follows:

Arab World English Journal for Translation \& Literary Studies 


\section{FR/ATR Condition}

$$
\begin{array}{ll}
\text { - } & \text { If [- back] then [+ ATR] } \\
\text { - } & \text { If [- back] then not [- ATR] }
\end{array}
$$

\section{The Qur'ānic/rs/Sound}

The alveolar trill in the Holy Qur'ān has two allophones, the pharyngealized $\left[\mathrm{r}^{\mathrm{c}}\right]$ and the nonpharyngealized $[\mathrm{r}]$. Previous studies offered different viewpoints regarding the underlying representation of the Qur'ānic alveolar trill sound. According to one claim, the pharyngealized $\left[\mathrm{r}^{\mathrm{S}}\right]$ and the non-pharyngealized [r] occur when it is adjacent to [+back] and [-back] sound, respectively. Thus, the underlying $/ r /$ is not pharyngealized. The other claim is that the pharyngealized $/ \mathrm{r}^{\mathrm{S}} /$ sound is regarded as an underlying representation because the nonpharyngealized [r] only occurs in a particular context, when adjacent to the /i/ or /i:/ (Altuwni, 1996). To determine this sound's underlying representation, we need to establish the environments in which the pharyngealized $\left[\mathrm{r}^{\mathrm{S}}\right]$ and non-pharyngealized $[\mathrm{r}]$ occur. The pharyngealized $\left[\mathrm{r}^{\mathrm{C}}\right]$ allophone occurs in the following environments:

1. The $\left[\mathrm{r}^{\mathrm{S}}\right]$ allophone occurs when it is followed by the /a/ or /a:/ phonemes

2. The $\left[\mathrm{r}^{\mathrm{S}}\right]$ allophone occurs when it is followed by the $/ \mathrm{u} / \mathrm{or} / \mathrm{u}: /$ phonemes

3. The $\left[\mathrm{r}^{\mathrm{S}}\right]$ allophone occurs when it is in the coda position, and the /a/ phoneme precedes it.

4. The $\left[\mathrm{r}^{\mathrm{S}}\right]$ allophone occurs when it is in the coda position, and the $/ \mathrm{u} /$ phoneme precedes it.

5. The $\left[\mathrm{r}^{\mathrm{r}}\right]$ allophone occurs when it is followed by the diphthongs /aj/ or /aw/.

6. The $\left[\mathrm{r}^{\mathrm{r}}\right]$ allophone occurs when it is preceded by the /i/ phoneme and followed by a pharyngealized phoneme.

Examples of the pharyngealized $\left[\mathrm{r}^{\zeta}\right]$ allophone are presented in the tables below:

\begin{tabular}{|c|c|}
\hline The Qur'anic Word & Its Meaning \\
\hline a) $\quad\left[\mathrm{r}^{\mathrm{S}} \mathrm{a} \text { matun }\right]^{\mathrm{i}}$ & Mercy \\
\hline b) [ðir ${ }^{\Upsilon} a:$ ajhi] & His forelegs \\
\hline c) [r'a:biGuhum] & The fourth of them \\
\hline
\end{tabular}

Table 1. The [r ${ }^{\complement}$ ] is Followed by /a/ or /a:/

Table 2. The [r $\left.{ }^{\complement}\right]$ is Followed by /u/ or /u:/

\begin{tabular}{|l|l|}
\hline The Qur'anic Word & Its Meaning \\
\hline a) $\quad\left[\mathrm{r}^{\mathrm{f}} \mathrm{u}\right.$ ba $]$ & Terror \\
\hline b) $\quad\left[\mathrm{r}^{\mathrm{f}} \mathrm{uqu}: \mathrm{d}\right]$ & They were asleep \\
\hline c) $\quad\left[\right.$ yastayfir $\left.{ }^{\varsigma} \mathrm{u}:\right]$ & They seek forgiveness \\
\hline d) $\quad\left[\right.$ ?anðir $\left.{ }^{\mathrm{u}} \mathrm{u}:\right]$ & They are warned \\
\hline
\end{tabular}

Arab World English Journal for Translation \& Literary Studies

ISSN: 2550-1542 | www.awej-tls.org 
AWEJ for Translation \& Literary Studies Volume, 5 Number 3. August 2021

Table 3. The $\left[r^{\uparrow}\right]$ is Preceded by the /al

\begin{tabular}{|c|l|}
\hline The Qur'anic word & Its Meaning \\
\hline a) $\quad\left[\right.$ PalPar $\left.^{\varsigma} d^{\varsigma} \mathrm{i}\right]$ & The earth \\
\hline b) $\quad\left[\right.$ zar $\left.^{\mathrm{S}} \mathrm{a} a\right]$ & Crops \\
\hline c) $\quad\left[\right.$ qar ${ }^{\varsigma}$ yatin $]$ & A town \\
\hline
\end{tabular}

Table 4. The $\left[r^{\complement}\right]$ is Preceded by the $/ u$ /

\begin{tabular}{|c|c|}
\hline The Qur'anic Word & Its Meaning \\
\hline a) [?aðkur $\left.{ }^{\mathrm{C}}\right]$ & Remember \\
\hline b) [nur'sila] & Send \\
\hline c) [mmurs $\left.\int \mathrm{ida}:\right]$ & Guide \\
\hline
\end{tabular}

Table 5. The [r $\left.r^{\complement}\right]$ is Followed by /aj/ or /aw/

\begin{tabular}{|c|l|}
\hline The Qur'anic Word & Its Meaning \\
\hline a) $\quad[\text { r'ajba }]^{2}$ & Doubt \\
\hline b) $\quad[$ Palbahr'ajni] & Two seas \\
\hline c) $\quad\left[\right.$ jar ${ }^{2}$ awna $]$ & They see \\
\hline
\end{tabular}

Table 6. The [ $\left.r^{\complement}\right]$ is Followed by a Pharyngealized Phoneme and Preceded by /i/

\begin{tabular}{|c|c|}
\hline The Qur'anic Word & Its Meaning \\
\hline [miris $\left.\mathrm{s}^{\Upsilon} \mathrm{a}: \mathrm{dan}\right]$ & Lying in wait \\
\hline b) [qirit $\left.t^{\mathrm{f} a} \mathrm{a}: \mathrm{s}\right]$ & Parchment \\
\hline
\end{tabular}

The non-pharyngealized [r] allophone occurs in the two following environments:

1. The [r] allophone occurs when it is preceded by the /i/ phoneme, and not followed by a pharyngealized phoneme.

2. The [r] allophone occurs when it is followed by the /i/ or /i:/ phonemes

Examples of the non-pharyngealized $[\mathrm{r}]$ allophone are exhibited in tables seven and eight:

Arab World English Journal for Translation \& Literary Studies 
AWEJ for Translation \& Literary Studies Volume, 5 Number 3. August 2021

Table 7. The [r] is Preceded by the /i/

\begin{tabular}{|c|l|}
\hline The Qur'anic Word & Its Meaning \\
\hline a) $[$ mirfaqa $]$ & Facility \\
\hline b) $[$ tunðirhum $]$ & Warn them \\
\hline c) $[$ nnayfir $]$ & We forgive \\
\hline
\end{tabular}

Table 8. The [r] is Followed by /i/ or /i:/

\begin{tabular}{|c|c|}
\hline The Qur'anic Word & Its Meaning \\
\hline a) [safarina:] & Our journey \\
\hline b) [?als $s^{\Upsilon} s^{\complement}$ awri] & Horn \\
\hline c) [mubafiri:na] & Tidings \\
\hline d) [munðiri:na] & Warners \\
\hline
\end{tabular}

The examples above show that the non-pharyngealized $[\mathrm{r}]$ allophone could be predictable. It occurs in a specific context, before a [-back] vowel or after a [-back] vowel and is not followed by a pharyngealized consonant. On the other hand, the pharyngealized $\left[\mathrm{r}^{\mathrm{S}}\right]$ appears as an elsewhere variant. In this case, it is reasonable to argue that the underlying representation of this alveolar trill phoneme in the holy Qur'ān is the pharyngealized $/ \mathrm{r}^{\mathrm{S}} /$ phoneme that is depharyngealized to $[\mathrm{r}]$ in specific contexts. This view is supported by Hayes (2009), who notes that the underlying form of a phoneme has an essential characteristic form in which it is altered in specific contexts by the phonology rules. He also states, "In a system of this kind, it is rational to adopt as the underlying representation of the phoneme its elsewhere allophone" (p.29).

\section{The Depharyngealization of the Qur'anic $/ r^{\varsigma} /$}

The descriptive generalization of the Qur'anic $/ \mathrm{r}^{\mathrm{f}} /$ depharyngealization is that the $/ \mathrm{r}^{\mathrm{s}} /$ phoneme must be depharyngealized when it is followed by a [-back] vowel. The same is true when the $/ \mathrm{r}^{\mathrm{r}} /$ is preceded by a [-back] vowel and not followed by a pharyngealized phoneme. The following two constraints establish the phonological process of the depharyngealization of the Qur'anic $/ \mathrm{r}^{\mathrm{s}} /$ sound:

(1)

a) $\mathrm{MAX}-\mathrm{IO}(+\mathrm{RTR})$ :

Every [+RTR] specification in the input must be presented in the output. The constraint requires that segments that are underlyingly emphatic remain so in the output (Mustafawi, 2006).

b) $[\mathrm{RTR}] \leftrightarrow \neg[\text {-back }]^{\text {ii }}$

A [RTR] feature must not be adjacent to a [-back] vowel.

i. $\quad(\leftrightarrow)$ means "adjacent."

ii. $\quad(\neg)$ means "not."

iii. [-back] represent vowels that are characterized by this feature, which are [i] and [i:].

Arab World English Journal for Translation \& Literary Studies

ISSN: 2550-1542 | www.awej-tls.org 
Constraint (1a) is a faithfulness constraint, which is needed to show why the losing candidate is ruled out in this analysis. As a result, this constraint favors the losing candidate *[safar ${ }^{\text {ina: }}$ :] since there is no deletion of the [RTR] feature. The faithfulness constraint IDENT-IO (place) is not utilized because it appears insufficient to account for the secondary pharyngealization. IDENTIO (place), which is the specification for the place of articulation of an input segment that must be preserved in its output correspondent, was first proposed by Kager (1999). The reason behind selecting constraint (1a) is the RTR feature associated with secondary pharyngealization. This is clearly manifested in the feature geometry representation. This representation provides insight into the secondary pharyngealization sounds' articulatory and phonological behavior in Arabic. The feature geometry representation of secondary pharyngealization was first proposed by Davis (1995). The feature-geometric representation shows that the root node of the primary place of articulation, called IPlace, is coronal and the secondary articulation, called 2Place, is pharyngeal. In addition, the RTR under the pharyngeal node indicates secondary pharyngealization, as shown in figure one. Thus, MAX-IO(+RTR) is an adequate faithful constraint for analyzing this phonological process.

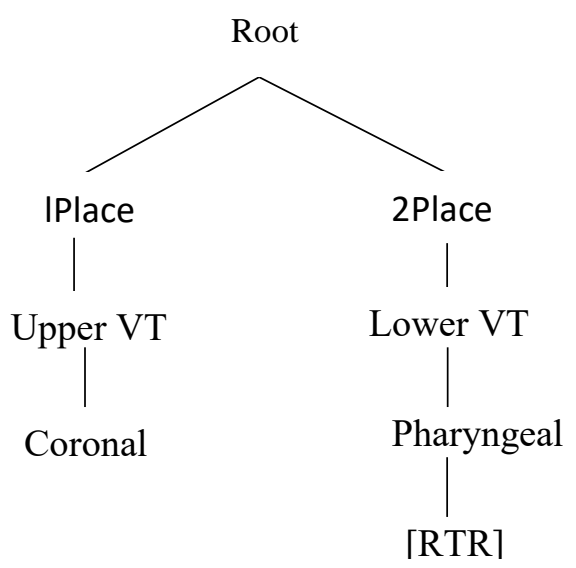

Figure 1. The representation of emphatics (Adopted from Davis, 1995, p.472)

Constraint (1b) is a markedness constraint that this study uses to describe a phoneme's depharyngealization when it is adjacent to a [-back] vowel. It is not violated unless the (RTR) feature is adjacent to [-back] vowel. The optimal candidate [safarina:] satisfies this constraint since the [r] allophone does not have an (RTR) feature adjacent to a [-back] vowel.

Cross-linguistically, this markedness constraint can be found in some Arabic dialects. For instance, in rural Palestinian Arabic, only a non-emphatic [r] can appear in a non-low [-back] vowel neighborhood. Additionally, in Baghdadi Arabic, the non-emphatic [r] is found before a [back] vowel [i/i:] (Youssef, 2019). Similarly, in Tunisian Arabic, the emphatic $/ \mathrm{r}^{\mathrm{f}} /$ does not retain its emphasis in the context of a [-back] vowel (Kriba, 2010). The ranking of the two constraints in (1) is presented in (2)

$$
[\mathrm{RTR}] \leftrightarrow \neg[\text {-back] } \gg \mathrm{MAX}-\mathrm{IO}(+\mathrm{RTR})
$$


AWEJ for Translation \& Literary Studies Volume, 5 Number 3. August 2021

The following tableaux show how the constraints interact with one another in the proposed ranking

Tableau (1)

\begin{tabular}{|l|l|l|}
\hline /safar ${ }^{\text {Sina:/ }}$ & {$[\mathrm{RTR}] \leftrightarrow \neg[$-back $]$} & $\mathrm{MAX}-\mathrm{IO}(+\mathrm{RTR})$ \\
\hline a) [safarina: $]$ & & $*$ \\
\hline b) [safar ${ }^{\text {Sina: }]}$ & $* \mathrm{~W}$ & $\mathrm{~L}$ \\
\hline
\end{tabular}

Tableau (2)

\begin{tabular}{|l|l|l|}
\hline$/$ mir $^{\mathrm{S}}$ faqa/ & {$[\mathrm{RTR}] \leftrightarrow \neg[$-back $]$} & $\mathrm{MAX}-\mathrm{IO}(+\mathrm{RTR})$ \\
\hline a) $[$ mirfaqa $]$ & & $*$ \\
\hline b) $\left[\mathrm{mir}^{\mathrm{S}}\right.$ faqa $]$ & $* \mathrm{~W}$ & $\mathrm{~L}$ \\
\hline
\end{tabular}

Tableau (1) demonstrates that (a) is the unfaithful winning candidate. It did not violate the undominated markedness constraint (1b) since the non-pharyngealized $[\mathrm{r}]$ that is followed by a [back] vowel does not have the [RTR] feature. Thus, it satisfies this constraint. However, it violates the lowest-ranked faithfulness constraint (1a) as there is deletion of the [RTR] feature. Candidate (b) is the losing candidate because it violates the highest-ranking markedness constraint while satisfying the dominated faithfulness constraint (1a). Therefore, the undominated markedness constraint (1b) favors the winning candidate [safarina:] over the losing candidate *[safar ${ }^{\text {ina:] }}$ while the dominated faithfulness constraint (1a) favors the losing candidate over the winning candidate.

Tableau (2) confirms the previous ranking which has a different input; a non-pharyngealized [r] allophone is preceded by a [-back] vowel and not followed by the pharyngealized phoneme. The optimal candidate is (a) because it did not violate the markedness (1b); the non-pharyngealized [r] that is preceded by a [-back] vowel does not have the [RTR] feature. However, it violates the lowest-ranked faithfulness constraint. (b) is the losing candidate because it violates the undominated constraint.

\section{Preservation of the Qur'anic Pharyngealized $/ r^{\S} /$}

The Qur'anic pharyngealized $/ \mathrm{r}^{\mathrm{q}} /$ phoneme must be preserved when the $/ \mathrm{r}^{\mathrm{q}} /$ is adjacent to a [+back] vowel or followed by diphthongs. Likewise, when the $/ \mathrm{r}^{\mathrm{S}} /$ phoneme is preceded by a [back] vowel and followed by a pharyngealized phoneme. The pharyngealized $/ \mathrm{r}^{\mathrm{f}} /$ phoneme is preserved because of the interaction of the faithfulness constraint (1b) and markedness like the one in (3a). Also, another markedness constraint is active such as the one in (3b) when the pharyngealized $/ \mathrm{r}^{\mathrm{S}} /$ is followed by a segment with (RTR) feature as in the word [qir ${ }^{\mathrm{S}} \mathrm{f}^{\mathrm{S}} \mathrm{a}: \mathrm{s}$ ].

Arab World English Journal for Translation \& Literary Studies 
AWEJ for Translation \& Literary Studies Volume, 5 Number 3. August 2021

(3)

a) *PHARYNGEAL:

It is a markedness constraint that is against pharyngealization (Gallagher, 2007).

b) SHARE (RTR): iii

Assign a violation to any sequence of segments not linked to the same token [RTR] feature. Constraint (3a) is a markedness constraint that is satisfied when there is no pharyngealization. Constraint (3b) is a markedness constraint that is satisfied when two adjacent segments share the same RTR feature. Also, this constraint can be satisfied by an underlying phoneme that does not have the [RTR] feature; therefore, there is no [RTR] feature spreading. This constraint is needed to show that the pharyngealized $/ \mathrm{r}^{\mathrm{S}} /$ sound is preserved when it is preceded by a [-back] vowel and followed by a pharyngealized phoneme. Hence, the pharyngealized segment shares its RTR feature with the pharyngealized $/ \mathrm{r}^{\mathrm{S}} /$. The ranking in (4) below shows that $/ \mathrm{r}^{\mathrm{S}} /$ is preserved when $t$ the $/ \mathrm{r}^{\mathrm{S}} /$ is adjacent to a [+back] vowel or followed by diphthongs.

(4) MAX-IO(+RTR) 》*PHARYNGEAL

Tableau 3 shows how the constraints interact with one another in the proposed ranking above:

Tableau (3)

\begin{tabular}{|c|c|c|}
\hline$/ \mathrm{r}^{\mathrm{S}} \mathrm{a \hbar m}$ atun/ & MAX-IO(+RTR) & *PHARYNGEAL \\
\hline a) $\left[\mathrm{r}^{\mathrm{C}} \mathrm{a \hbar matun}\right]$ & & $*$ \\
\hline b) [raћmatun] & $* \mathrm{~W}$ & $\mathrm{~L}$ \\
\hline
\end{tabular}

Tableau (3) shows that the winner is the faithful candidate (a) because the pharyngealized $\left[\mathrm{r}^{\mathrm{q}}\right]$ is followed by the [+back] vowel; hence, it is preserved in the output form. Thus, it satisfies the highest-ranking faithfulness constraint (1a). On the other hand, it violates the lowest-ranking markedness constraint (3a). The losing candidate (b) satisfies the lowest-ranking markedness constraint because the $[\mathrm{r}]$ is not pharyngealized. However, it violates the highest-ranked constraint (1a) since the pharyngealized $\left[\mathrm{r}^{\mathrm{S}}\right]$ input form is not preserved. Therefore, the faithfulness constraint (1a) favors the winning candidate $\left[\mathrm{r}^{\mathrm{S}}\right.$ ahmatun] over the losing candidate $*$ [rahmatun] while the markedness constraint ( $3 \mathrm{a}$ ) favors the losing candidate over the winning candidate.

The ranking in (5) demonstrates that the pharyngealized $/ \mathrm{r}^{\mathrm{f}} /$ is preserved when the $/ \mathrm{r}^{\mathrm{f}} /$ is preceded by a [-back] vowel and followed by a pharyngealized phoneme.

(5) $\quad$ SHARE (RTR) 》 [RTR $] \leftrightarrow \neg[$-back $]$

Tableau (4)

\begin{tabular}{|l|l|l|}
\hline$/$ qir $^{\mathrm{S} \mathrm{t}^{\mathrm{f}} \mathrm{a}: \mathrm{s} /}$ & SHARE $(\mathrm{RTR})$ & {$[\mathrm{RTR}] \leftrightarrow \neg[$-back] } \\
\hline a) $\left[\right.$ qir $\left.^{\mathrm{C}} \mathrm{t}^{\mathrm{f}} \mathrm{a}: \mathrm{s}\right]$ & & $*$ \\
\hline
\end{tabular}

Arab World English Journal for Translation \& Literary Studies

ISSN: 2550-1542 | www.awej-tls.org 
AWEJ for Translation \& Literary Studies Volume, 5 Number 3. August 2021

\begin{tabular}{|l|l|l|}
\hline b) [qirt $\left.{ }^{\varsigma} \mathrm{a}: \mathrm{s}\right]$ & $* \mathrm{~W}$ & $\mathrm{~L}$ \\
\hline
\end{tabular}

Tableau (4) illustrates that the winning candidate is (a). This is because the pharyngealized $\left[\mathrm{r}^{\mathrm{S}}\right]$ is followed by a segment with [RTR] feature. As a result, the pharyngealized $\left[\mathrm{r}^{\mathrm{S}}\right]$ is preserved in the output form. Thus, it satisfies the highest-ranked markedness constraint (3b). On the other hand, it violates the lowest-ranked markedness constraint (1b). The losing candidate is (b). It violates the highest-ranked constraint (3b). Nevertheless, the losing candidate (b) satisfies the lowest-ranking markedness constraint ( $1 b$ ). Therefore, the markedness constraint ( $3 b$ ) favors the

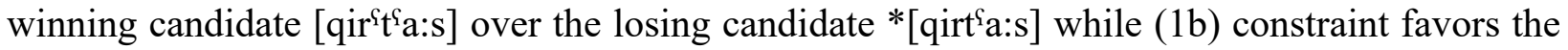
losing candidate over the winning candidate.

\section{The Qur'ānic // Sound}

The alveolar lateral /1/ in the holy Qur'ān has two allophones, the pharyngealized [1 $\left.{ }^{\mathrm{i}}\right]$ and the non-pharyngealized [1]. The pharyngealized [ $\left.1^{\mathrm{l}}\right]$ only occurs in the word Allah. Hence, $/ 1 /$ in the word Allah "Lamul-Jalalah" has two allophones, the pharyngealized $\left[{ }^{\mathrm{S}}\right]$ and the nonpharyngealized [1]. The pharyngealized $\left[1^{\mathrm{I}}\right]$ and non-pharyngealized [1] occur in the following cases:

1. The $\left[1^{1}\right]$ allophone occurs in the word Allah when it is preceded by a word-final or prefixfinal /a/ or /a:/ vowels.

2. The pharyngealized $\left[1^{\varsigma}\right]$ allophone occurs in the word Allah when it is preceded by a wordfinal or prefix-final /u/ or /u:/ vowels.

The tables below illustrate examples of the pharyngealized $\left[1^{\mathrm{l}}\right]$ allophone:

Table 8. The [l'] in the Word Allah is Preceded by a Word-Final or Prefix-Final /a/ or /a:/

\begin{tabular}{|c|c|}
\hline The Qur'anic Word & Its Meaning \\
\hline a) [huwa Pa $\left.1^{\complement} l^{\varsigma} \mathrm{a}: \mathrm{hu}\right]$ & $\mathrm{He}$ is Allah \\
\hline 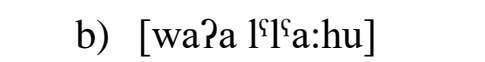 & And Allah \\
\hline c) [kallama Pa $\left.1^{1}{ }^{1}{ }^{\varsigma} a: h u\right]$ & To whom Allah spoke \\
\hline d) [ [a:?a Pa $\left.\left.l^{1}\right|^{\varsigma} a: h u\right]$ & Allah had willed \\
\hline e) [waka:na Pa $\left.1^{\complement} 1^{\varsigma} a: h u\right]$ & And Allah is ever \\
\hline f) [waSala: Pa $\left.1^{\varsigma} l^{\varsigma} a: h i\right]$ & About Allah \\
\hline
\end{tabular}

Table 9. The [l' $]$ in the Word Allah is Preceded by a Word-Final or Prefix-Final /u/ or /u:/

\begin{tabular}{|c|c|}
\hline The Qur'anic Word & Its Meaning \\
\hline a) [yamћaqu Pal $\left.{ }^{\varsigma} l^{\varsigma} \mathrm{a}: \mathrm{hu}\right]$ & Allah destroys \\
\hline b) [Pattaqu: $\left.\operatorname{Pal}^{\uparrow}\right|^{\uparrow} \mathrm{s}: \mathrm{ha}$ & Fear Allah \\
\hline
\end{tabular}

Arab World English Journal for Translation \& Literary Studies 
AWEJ for Translation \& Literary Studies Volume, 5 Number 3. August 2021

c) [Callamahu Pal' $\left.{ }^{\varsigma} \mathrm{S} a \mathrm{~h}\right]$

d) [waraðkuru: Ral $\left.l^{\uparrow} l^{\uparrow} a: h a\right]$

e) [hudu:du Pal```a:hi]

Allah has taught him

And remember Allah

Limits of Allah

On the other hand, the non-pharyngealized [1] occurs in the following cases, and its examples are shown in tables 10 and 11 :

1. The non-pharyngealized [1] in the word Allah occurs when it preceded by word-final or prefix-final /i/ vowel.

2. The non-pharyngealized [1] in other contexts.

Table 10. The [l] in the Word Allah is Preceded by a Word-Final or Prefix-Final /i/

\begin{tabular}{|l|l|}
\hline The Qur'anic Word & Its Meaning \\
\hline a) [quli Palla:hu] & Say Allah \\
\hline b) [Paja:ti Palla:hi] & Signs of Allah \\
\hline c) [biPalla:hi] & In Allah \\
\hline d) [lilla:hi] & To Allah \\
\hline
\end{tabular}

Table 11. The [l] in Other Contexts

\begin{tabular}{|c|l|}
\hline The Qur'anic Word & Its Meaning \\
\hline a) [Panzala] & Sent down \\
\hline b) [qulu:bihim] & Hearts \\
\hline c) $[$ Palhamdu $]$ & Praise \\
\hline
\end{tabular}

The above data shows that the pharyngealized $\left[\left[^{\mathrm{l}}\right]\right.$ allophone in the word Allah appears when it is preceded by a word or prefix that ends with a [+back] vowel /a/, /a:/, /u/, or /u:/. On the other hand, the [1] allophone in the word Allah occurs when it is adjacent to a word or prefix that ends with a [-back] vowel /i/.

\section{The Pharyngealization of the Qur'anic //}

The descriptive generalization of the Qur'anic /l/ pharyngealization is that the /l/ sound in the

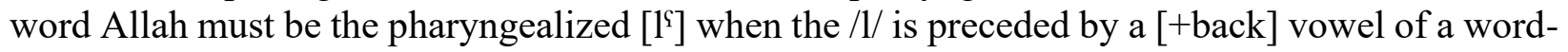
final or prefix-final. The phonological analysis of the $\left[1^{\complement}\right]$ pharyngealization in the holy Qur'an is based on the following three constraints:

Arab World English Journal for Translation \& Literary Studies

ISSN: 2550-1542 | www.awej-tls.org 
AWEJ for Translation \& Literary Studies Volume, 5 Number 3. August 2021

\section{a) IDENT [1]}

A light /1/ in the input must remain light in the output (Turton, 2012).

b) /1/ IS DARK $\leftrightarrow$ morpheme [+back]]

A lateral segment is dark when it is preceded by a [+back] morpheme-final segment.

Constraint (6a) is a faithfulness constraint in which the light [1] presents the non-pharyngealized [1]. This constraint requires the output to preserve the non-pharyngealized [1]. Hence, this constraint favors the losing candidate *[huwa Palla:h] over the winning candidate [huwa Pal' ${ }^{\complement} \mathrm{l}^{\mathrm{f}} \mathrm{a}: \mathrm{h}$ ].

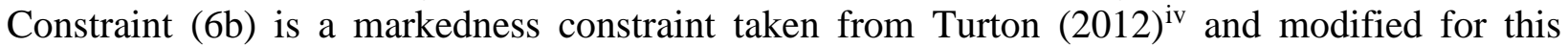
analysis. The pharyngealized $\left[1^{\mathrm{C}}\right]$ is represented by the dark [1]. This markedness constraint describes the pharyngealized $\left[1^{\mathrm{l}}\right]$ when it occurs in a context preceded by a morpheme-final [+back] vowel. Hence, the constraint favors the winning candidate [huwa $\mathrm{Pal}^{\mathrm{\zeta}} \mathrm{l}^{\mathfrak{}} \mathrm{a}: \mathrm{h}$ ]. The ranking of these two constraints is shown in (7).

(7) $\quad /$ l/ IS DARK $\leftrightarrow$ morpheme [+back]] >> IDENT [1]

The tableaux below demonstrate how the constraints interact with one another in the proposed ranking:

Tableau (5)

\begin{tabular}{|l|l|l|}
\hline /huwa Palla:h/ & /l/ IS DARK $\leftrightarrow$ morpheme [+back]] & IDENT [1] \\
\hline a) [huwa Pal```a:h] & & $*$ \\
\hline b) [huwa Palla:h] & $* \mathrm{~W}$ & $\mathrm{~L}$ \\
\hline
\end{tabular}

Tableau (6)

\begin{tabular}{|l|l|l|}
\hline$/$ waPall a:hu / & /l/ IS DARK $\leftrightarrow$ morpheme [+back]] & IDENT [1] \\
\hline a) [waPal'l`a:hu] & & $*$ \\
\hline b) [wa2all a:hu] & $* \mathrm{~W}$ & $\mathrm{~L}$ \\
\hline
\end{tabular}

Tableau (5) demonstrates that candidate (a) is the unfaithful winning candidate. It did not violate the undominated markedness constraint (6b) since the pharyngealized $\left[^{\mathrm{l}}\right]$ occurs after a word-final [+back] vowel. Thus, it satisfies this constraint. However, it violates the lowestranked faithfulness constraint (6a) since the non-pharyngealized /l/ in the input did not remain non-pharyngealized in the output form. Candidate (b) is the losing candidate because it violates the highest-ranking markedness constraint (6b) since the /1/ is not pharyngealized in a context where it is preceded by a morpheme-final [+back] vowel. However, it satisfies the dominated faithfulness constraint (6a). Thereby, the highest-ranked markedness constraint (6b) favors the winning candidate [huwa Pal $\left.{ }^{\complement} l^{\complement} a: h\right]$ over the losing candidate *[huwa Palla:h]. On the other hand, the dominated faithfulness constraint (6a) favors the losing candidate over the winning candidate.

Tableau (6) also illustrates the previous ranking (7). This tableau has a different input where the word Allah is preceded by a prefix. The optimal candidate is (a) because it did not violate the undominated markedness constraint (6b), considering the pharyngealized $\left[1^{\mathrm{l}}\right]$ appears after a 
AWEJ for Translation \& Literary Studies Volume, 5 Number 3. August 2021

prefix-final [+back] vowel. However, it violates the lowest-ranked faithfulness constraint (6a). The losing candidate (b) violates the highest-ranked constraint as the /l/ is not pharyngealized before a prefix-final [+back] vowel.

\section{The Qur'ānic /a:/Sound}

The Qur'ānic pharyngealized sounds $/ \mathrm{t}^{\mathrm{q}} /, / \mathrm{d}^{\mathrm{q}} /, / \mathrm{s}^{\mathrm{q}} /, / \mathrm{\delta}^{\mathrm{q}} /, / \chi^{\mathrm{q}} /, / \mathrm{q}^{\mathrm{q}} /, / \mathrm{\gamma}^{\mathrm{q}} /, / \mathrm{r}^{\mathrm{q}} /$ or the pharyngealized $\left[1^{\mathrm{I}}\right]$ in the word Allah spreads their secondary articulation rightwards to /a:/. Hence, the low [+back] long vowel /a:/ has two allophones in the Holy Qur'ān, the pharyngealized [a: $\left.{ }^{\complement}\right]$ and the nonpharyngealized [a:]. The pharyngealized [a: $\left.:^{\complement}\right]$ occurs when a pharyngealized phoneme precedes it, which results from the [RTR] feature that is found in the underlying form of the preceding pharyngealized sounds. Also, the /a:/ sound in the word Allah is pharyngealized when the /l/ sound is pharyngealized. The pharyngealized $\left[1^{\mathrm{I}}\right]$ has [RTR] feature that spreads to /a:/. Therefore, the /a:/ sound acquires the [RTR] feature in its surface form. Conversely, the non-pharyngealized [a:] is an elsewhere allophone. The following data demonstrate the pharyngealized [a: $\left.{ }^{\complement}\right]$ and the nonpharyngealized [a:] environments. Table 12 shows that the pharyngealized [a: $\left.{ }^{\complement}\right]$ allophone occurs when a pharyngealized phoneme precedes it. Table 13, on the other hand, exhibits the nonpharyngealized [a:] environments.

Table 12. The [a: $\left.{ }^{\complement}\right]$ Preceded by a Pharyngealized Phoneme

\begin{tabular}{|c|c|}
\hline The Qur'anic Word & Its Meaning \\
\hline 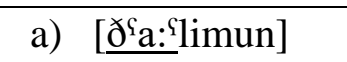 & Unjust \\
\hline b) $\left[\underline{S}^{\mathrm{S} a} \mathrm{e}^{\mathrm{S}}\right.$ hibuhu & Companion \\
\hline 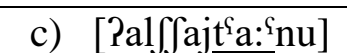 & Satan \\
\hline 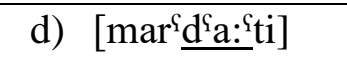 & Approval \\
\hline e) $\left[\mathrm{q}^{\complement} \mathrm{a}:{ }^{\mathrm{S}} \mathrm{mu}:\right]$ & They stood \\
\hline f) [yuy $\left.{ }^{\mathrm{s} a}:{ }^{\ominus} \theta \mathrm{u}:\right]$ & They will be relieved \\
\hline g) $\left[\chi^{\mathrm{S} a}:{ }^{\zeta}\right.$ lidi:na $]$ & Wherein they abide eternally \\
\hline 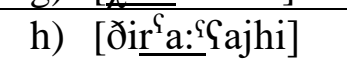 & Foreleg \\
\hline 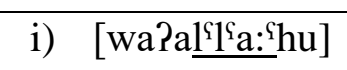 & And Allah \\
\hline
\end{tabular}

Table 13. The [a:] Preceded by a Non-Pharyngealized Phoneme

\begin{tabular}{|c|c|}
\hline The Qur'anic Word & Its Meaning \\
\hline (8) [?alkita:ba] & The book \\
\hline 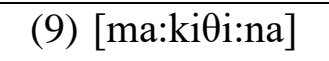 & They will remain \\
\hline (10) [dzaSalna:] & We have made \\
\hline
\end{tabular}

Table 12 shows that the [a: $\left.{ }^{[}\right]$is pharyngealized when it is preceded by a pharyngealized sound. Example (h) exhibits that the underlying pharyngealized $/ \mathrm{r}^{\mathrm{f}} /$ is preserved since it is in the onset 
position followed by [+back]. Hence, the pharyngealized $/ \mathrm{r}^{\mathrm{\varsigma}} /$ spreads its [RTR] feature to the [a:]. Example (i) shows that the /l/ is pharyngealized in the word Allah since it is preceded by morpheme-final [+back] vowel. Consequently, the [1] spreads its [RTR] feature to the [a:] that follows it.

\section{The Pharyngealization of the Qur'anic / a:/}

The descriptive generalization of the Qur'anic /a:/ pharyngealization is that the /a:/ phoneme must be pharyngealized when a pharyngealized sound precedes it. Thus, in the Holy Qur'an, there is a rightward spread of the [RTR] feature of the pharyngealized sound to [a:]. This is based on two constraints: a markedness constraint (3b) and a faithfulness constraint like the one in (8).

\section{(8) IDENT(-RTR)}

[-RTR] segments in the input must remain [-RTR] in the output (Khedidja \& Zhang, 2017).

Constraint (3b) is needed in this analysis to show how the pharyngealized sound shares the

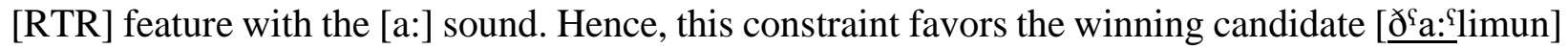
over the losing candidate ${ }^{*}\left[{ }^{\Upsilon} \mathrm{a}\right.$ :limun]. Constraint (8) is a faithfulness constraint that requires the output candidate to preserve the non-pharyngealized [a:] and is needed to show why the losing candidate is ruled out. This faithfulness constraint favors the losing candidate * [ ${ }^{\varsigma}$ a:limun] over the winning candidate [ $\partial^{\varsigma} \mathrm{a}:{ }^{:}$limun]. The ranking of these two constraints is shown in (9).

(9) SHARE (RTR) >> IDENT(-RTR)

Tableau (7)

\begin{tabular}{|c|c|c|}
\hline /ðీa:limun/ & SHARE (RTR) & IDENT(-RTR) \\
\hline 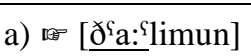 & & * \\
\hline b) [ð`a:limun] & $* \mathrm{~W}$ & $\mathrm{~L}$ \\
\hline
\end{tabular}

Tableau (7) demonstrates the ranking above. The optimal output is the candidate (a) because it satisfies the markedness constraint (3b), which is the highest-ranking constraint. This is because the [RTR] feature of the pharyngealized phoneme has spread to the /a:/ sound. On the other hand, it violates the lowest-ranking faithfulness constraint (8), as the non-pharyngealized /a:/ in the input did not preserve its form in the output. Candidate (b) is the losing candidate because it violates the highest-ranking markedness constraint (3b), though it satisfies the dominated faithfulness constraint (8). Therefore, the highest-ranking markedness constraint (3b) favors the winning

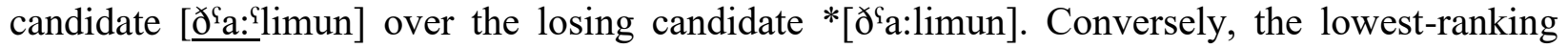
faithfulness constraint (8) favors the losing candidate over the winning candidate.

Tableau (8)

\begin{tabular}{|c|c|c|}
\hline /ðir`a:Yajhi/ & SHARE (RTR) & IDENT(-RTR) \\
\hline 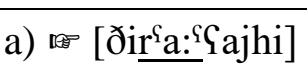 & & $*$ \\
\hline b) [ðir'a:Yajhi] & $* \mathrm{~W}$ & $\mathrm{~L}$ \\
\hline
\end{tabular}

Arab World English Journal for Translation \& Literary Studies

ISSN: 2550-1542 | www.awej-tls.org 
AWEJ for Translation \& Literary Studies Volume, 5 Number 3. August 2021

Tableau (8) also illustrates the previous ranking (9). This tableau has a different input where the pharyngealized $/ \mathrm{r}^{\mathrm{S}} /$ is in the onset position and is followed by the [+back] phoneme. Candidate (a) is the winning as it satisfies the highest-ranked constraint (3b). This is because the pharyngealized $/ \mathrm{r}^{\mathrm{f}} /$ spreads its [RTR] feature rightward to the /a:/. Nevertheless, it violates the lowest-ranked constraint (8). Candidate (b) is eliminated as it violates the highest-ranked markedness constraint (3b).

The [a:] sound is pharyngealized in the word Allah since it is preceded by a pharyngealized $\left[1^{\complement}\right]$ allophone; hence, there are two processes: the [1] pharyngealization when preceded by a morpheme-final [+back] vowel and the [a: $:^{\complement}$ pharyngealization where it is preceded by the pharyngealized $\left[1^{\complement}\right]$ allophone. This is based on the ranking that is given in (10)

(10) /l/ IS DARK ↔ morpheme [+back]], SHARE (RTR) 》 IDENT [1], IDENT(-RTR)

Tableau (9)

\begin{tabular}{|c|c|c|c|c|}
\hline / waPall a:hu / & $\begin{array}{l}\text { /l/ IS DARK } \\
\leftrightarrow \text { morpheme [+back]] }\end{array}$ & $\begin{array}{l}\text { SHARE } \\
\text { (RTR) }\end{array}$ & IDENT [1] & $\begin{array}{l}\text { IDENT } \\
(-\mathrm{RTR})\end{array}$ \\
\hline a) $\left[\mathrm{waPal}^{\mathrm{C}} \mathrm{l}^{\mathrm{S} a}: \mathrm{s}^{\mathrm{S}} \mathrm{hu}\right.$ & & & $*$ & $*$ \\
\hline b) [waPal $\left.{ }^{\mathrm{S}} \mathrm{l}^{\mathrm{S}} \mathrm{a}: \mathrm{hu}\right]$ & & $* \mathrm{~W}$ & $*$ & $\mathrm{~L}$ \\
\hline c) [ wa?alla:hu] & $* \mathrm{~W}$ & & $\mathrm{~L}$ & \\
\hline
\end{tabular}

Tableau (9) supports the ranking (10). It shows that the optimal candidate is (a) since it satisfies the highest-ranked markedness constraints (6b) and (3b). However, it violates the dominated faithfulness constraints (6a) and (8). Candidate (b) is ruled out because it violates the highestranked markedness constraint (3b). This is because the [a:] surfaces as a non-pharyngealized sound preceded by the pharyngealized $\left[1^{\mathrm{S}}\right]$. Also, candidate (c) is ruled out since it violates the undominated markedness constraint $(6 \mathrm{~b})$.

The constraint rankings that account for the three Qur'ānic conditionally pharyngealized sounds $/ \mathrm{r}^{\mathrm{\complement}} /, / 1 /$, and $/ \mathrm{a}: /$ are summarized in table (14):

Table 14. The Constraint Rankings of the Qur'änic Conditionally Pharyngealized Sounds

\begin{tabular}{|l|l|}
\hline \multicolumn{1}{|c|}{ The Phonological Process } & \multicolumn{1}{c|}{ The Ranking } \\
\hline a) $\begin{array}{l}\text { The depharyngealization of the } \\
\text { Qur'ānic } / \mathrm{r}^{\mathrm{f}} /\end{array}$ & $[\mathrm{RTR}] \leftrightarrow \neg[$-back $] \gg$ MAX-IO(+RTR $)$ \\
\hline \begin{tabular}{l} 
b) $\begin{array}{l}\text { The pharyngealization of the } \\
\text { Qur'ānic } / 1 / \text { in the word Allah }\end{array}$ \\
\hline
\end{tabular} & $\begin{array}{l}/ 1 / \text { IS DARK } \leftrightarrow \text { morpheme }[+ \text { back }]]>>\text { IDENT } \\
{[1]}\end{array}$ \\
\hline
\end{tabular}

Arab World English Journal for Translation \& Literary Studies 
AWEJ for Translation \& Literary Studies Volume, 5 Number 3. August 2021

The Quranic Conditionally Pharyngealized Sounds

Almousa \& Al-Mohanna

c) The pharyngealization the Qur'ānic a:/

SHARE (RTR) >> IDENT(-RTR)

\section{Discussion}

The current study fully analyzed the Qur'ānic conditionally pharyngealized sounds. Through the analysis, this study has confirmed that the underlying representation of the Qur'ānic alveolar trill sound is the pharyngealized $/ \mathrm{r}^{\mathrm{S}} /$. This was achieved by demonstrating environments for both the $\left[\mathrm{r}^{\mathrm{\complement}}\right]$ and $[\mathrm{r}]$ allophones and establishing the complementary distribution. The $/ \mathrm{r}^{\mathrm{\complement}} /$ is depharyngealized when it is adjacent to [- back] vowels. Thus, the depharyngealization of $/ \mathrm{r}^{\mathrm{S}} /$ is achieved through two constraint interactions: MAX-IO (+RTR) and [RTR] $\neg \neg[-$ back]. The [RTR] $\leftrightarrow \neg[$-back] constraint is ranked higher than MAX-IO(+RTR). A markedness constraint against pharyngealization was also given to show the preservation of the Qur'anic pharyngealized $/ \mathrm{r}^{\mathrm{q}} /$. *PHARYNGEAL is ranked below MAX-IO (+RTR). Additionally, the $/ \mathrm{r}^{\mathrm{\complement}} /$ preservation is achieved through ranking SHARE (RTR) above MAX-IO (+RTR) when the $/ \mathrm{r}^{\mathrm{f}} /$ is preceded by a [-back] vowel and followed by pharyngealized phoneme is given.

This study has supported Amer's (2016) observation that the phoneme /1/ has two allophones in the Qur'an: the pharyngealized [1] and non-pharyngealized [1]. Also, this study compared the pharyngealized $\left[1^{\mathrm{S}}\right]$ and non-pharyngealized [1] in the word Allah to the dark $/ 1 /$ in English. As Amer (2001) mentioned, the dark [1] in English appears in final positions and after consonants, while the clear [1] appears in initial and medial positions. However, this study revealed that the pharyngealized $\left[1^{\complement}\right]$ in the word Allah only occurs after a morpheme final [+back] vowel. Further, two constraints were noted in this study for the pharyngealization of /1/: IDENT [1] and /1/ IS DARK $\leftrightarrow$ morpheme [+back]]. /l/ IS DARK $\leftrightarrow$ morpheme [+back]] dominates IDENT [1].

The study also has noted that the Qur'ānic /a:/ is the pharyngealized when it occurs in a context

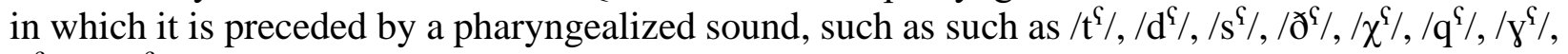
$/ \mathrm{r}^{\mathrm{S}} /$, or $\left[1^{\mathrm{\complement}}\right]$ in the word Allah. Hence, the pharyngealized sound has spread its [RTR] feature to the /a:/. As a result, the /a:/ acquires the preceding pharyngealized sound's feature. The analysis demonstrated that the $\left[a::^{\mathrm{S}}\right]$ pharyngealization is achieved through two constraint interactions: SHARE (RTR) and IDENT(-RTR). The markedness SHARE (RTR) constraint dominates the faithfulness IDENT(-RTR) constraint. The two questions posed in this study were completely addressed by the OT analysis.

\section{Conclusion}

This paper has addressed the three conditionally pharyngealized sounds $/ \mathrm{r}^{\mathrm{S}} /, / 1 /$, and $/ \mathrm{a}: /$, in Qur'annic recitation within the OT framework with the goal of analyzing the depharyngealization of the $/ \mathrm{r}^{\mathrm{f}} /$ and the pharyngealization of the /1/ and /a:/. The two questions posed by this study were entirely answered by the OT analysis. In analyzing the Qur'ānic $/ \mathrm{r}^{\mathrm{S}} /$ sound, this study determined that the underlying form of this sound is the pharyngealized $/ \mathrm{r}^{\mathrm{\complement}} /$. The $/ \mathrm{r}^{\mathrm{\complement}} /$ surface as a nonpharyngealized sound when it is adjacent to [-back] vowels, namely /i/ or /i:/. In addition, this 
study pointed out that the Qur'anic pharyngealized $/ \mathrm{r}^{\mathrm{f}} /$ is preserved when it is adjacent to a [+back] vowel. The pharyngealized $/ \mathrm{r}^{\mathrm{\varsigma}} /$ is also preserved when the $/ \mathrm{r}^{\mathrm{\varsigma}} /$ is preceded by a [-back] vowel and followed by a pharyngealized phoneme. The study showed that the Qur'anic /1/ has two allophones in the Holy Qur'ān. The pharyngealized $\left[1^{\complement}\right]$ allophone only occurs in the word Allah while the nonpharyngealized [1] allophone occurs in the word Allah and other contexts. The study also reported that the pharyngealized $\left[1^{\complement}\right]$ and non-pharyngealized [1] in the word Allah are similar to the dark [1] and the clear [1] in English. The /1/ is pharyngealized when the / $1 /$ is adjacent to a word-final or prefix-final [+back] vowel. The Qur'anic /a/ acquires the [RTR] feature from the preceded

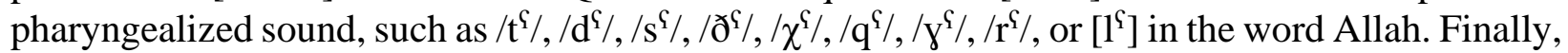
this paper indicates that the OT framework could be used to examine the Quranic pharyngealization and depharyngealization processes.

\section{Endnotes}

'The data that is used in this study were taken directly from the holy Qur'ān from Surah Al-Kahf, Al-Baqarah, AlAn'am, and Al-Naba.

ii The format of constraint-enforcing adjacency is adopted from the markedness constraint Stop $\left(\neg \_\right.$[+cont]) $\leftrightarrow$ V: A stop that is not followed by a [+continuant] segment is adjacent to a vowel (Côté, 2000)

iii This constraint is taken from Khedidja and Zhang (2017). They utilized this markedness constraint for a CV sequence.

iv /I/ IS DARK the main constraint

About the Authors:

Fatima Abdullah Almousa holds a bachelor's degree in English Language and Literature from the College of Languages and Translation in 2017 from Imam Muhammad Ibn Saud Islamic University. She then earned a master's degree in Arts in Theoretical Linguistics from King Saud University in 2021. Her research interest is in the phonology field. ORCID ID: https://orcid.org/0000-0001-9490-6564

Faisal M. Al-Mohanna is an Associate Professor of Linguistics (Phonology) at the Department of Linguistics and Translation Studies, King Saud University. His latest academic qualification is $\mathrm{PhD}$ in Linguistics (Phonology), University of Essex 1998. His main research interests are Prosodic Phonology, Metre, and Optimality Theory. He has work experience in academic and cultural administration, Teaching Linguistics, and Teaching English to speakers of other languages. ORCID ID: https://orcid.org/0000-0002-5968-0835

\section{References}

Amer, A.A. (2016). The Universal Nature of the Qur'an's Phonetics. Arab World English Journal, 7(3), 187-198.

Arab World English Journal for Translation \& Literary Studies 
AWEJ for Translation \& Literary Studies Volume, 5 Number 3. August 2021

Amer, W. M. (2001). An investigation into the differences between English and Arabic consonant and vowel sounds: A contrastive study with pedagogical implications. Site. iugaza. edu. ps. The Islamic University of Gaza. Available at http://hdl.handle.net/20.500.12358/25636

Aldamen, H. A. K. (2013). The production of emphasis by second language learners of Arabic, (Unpublished Doctoral dissertation). University of Kansas, United States.

Al-Hashmi, S. A. (2004). The Phonology of nasal $n$ in the Language of the Holy Qur'an BA, Sultan Qaboos University, (Unpublished Master's thesis). University of Victoria.

Alhammad, R. (2014). Emphasis spread in Najdi Arabic (Doctoral dissertation), California State University, Fresno. Available at DOI:10.13140/RG.2.2.10890.62406

Al-Masri, M., \& Jongman, A. (2004). Acoustic correlates of emphasis in Jordanian Arabic:

Preliminary results, University of Kansas, 96-106.

Alsurf, S. S. S. (2013). The Phonetics of the Qur'anic pharyngealised sounds: acoustic and articulatory studies, (Doctoral dissertation). Macquarie University, Sydney, Australia Available at http://hdl.handle.net/1959.14/305125.

Al-Tamimi, F., Alzoubi, F., \& Tarawnah, R. (2009). A videofluoroscopic study of the emphatic consonants in Jordanian Arabic. Folia Phoniatrica et Logopaedica, 61(4), 247-253. Available at https://doi.org/10.1159/000235644

Altuwni, M. (1996) Dirasat Sawtiat Lilrra' Fi Daw' Alqara'at Alqurania [An acoustic study of the $R$ in light of the Qur'anic recitation]. Journal department of Dar Aleulum, 20, 67-110.

Alwabari, S. (2020). Phonological and physiological constraints on assimilatory pharyngealization in Arabic: Ultrasound study, (Unpublished Doctoral dissertation). University of Ottawa, Canada.

Binasfour, H. S. M. (2018). Investigating the perception and production of the Arabic pharyngealised sounds by L2 learners of Arabic, (Unpublished Doctoral dissertation). University of Reading.

Bin-Muqbil, M. S. (2006). Phonetic and phonological aspects of Arabic emphatics and gutturals. The University of Wisconsin-Madison.

Chomsky, N., \& Halle, M. (1968). The Sound Pattern of English. New York: Harper and Row

Côté, Marie-Hélène. (2000). Consonant cluster phonotactics: A perceptual approach, (Unpublished Doctoral Dissertation). Massachusetts Institute of Technology

Available at https://doi.org/doi:10.7282/T3HD7TGR

Davis, S. (1995). Emphasis spread in Arabic and grounded phonology. Linguistic Inquiry, 465498.

Druel, J. (2006). Emphatic sounds in educated Cairene Arabic, (Unpublished Master's thesis). The American University in Cairo. Available at https://fount.aucegypt.edu/retro_etds/2002

Elhassan, E. M. (2015). Investigating the role of mastering the rules of Holy Quran recitation in English pronunciation, (Unpublished Doctoral dissertation). Sudan University of Science and Technology.

Ferguson, C. A. (1956). The emphatic l in Arabic. Language, 32(3), 446-452

Arab World English Journal for Translation \& Literary Studies

ISSN: 2550-1542 | www.awej-tls.org 
AWEJ for Translation \& Literary Studies Volume, 5 Number 3. August 2021

Gadoua, A. H. (2000). Consonant clusters in Quranic Arabic. Cahiers Linguistiques d'Ottawa, 59-86. Retrieved from http://clo.canadatoyou.com/28/Gadoua(2000)CLO28_61-85.pdf

Gallagher, G. (2007). Diachronic and synchronic pharyngealization in West Greenlandic. In Proceedings of the Workshop in General Linguistics, LSO Working Papers in Linguistics (pp.95-108). Available at https://langsci.wisc.edu/wpcontent/uploads/sites/1012/2019/05/gallagher.pdf

Halle M., \& Mohanan, K. P. (1985). Segmental phonology of Modern English. Linguistic Inquiry, 16, 57-116

Hayes, B. (2009). Introductory Phonology. Wiley-Blackwell.

Hoberman, R. D. (1985). The phonology of pharyngeals and pharyngealization in pre-modern Aramaic. Journal of the American Oriental Society 105 (2), 221-231. Available at https://doi.org/10.2307/601702

Johnson, W., \& Britain, D. (2007). L-vocalisation as a natural phenomenon: Explorations in sociophonology. Language Sciences, 29(2-3), 294-315.

DOI:10.1016/j.langsci.2006.12.022

Jongman, A., Herd, W., Al-Masri, M., Sereno, J., \& Combest, S. (2011). Acoustics and perception of emphasis in Urban Jordanian Arabic. Journal of Phonetics, 39(1), 85-95.

Kager, R. (1999). Optimality Theory. Cambridge University Press.

Kahn, M. (1975). Arabic emphatics: The evidence for cultural determinants of phonetic sextyping. Phonetica, 31(1), 38-50. Available at https://doi.org/10.1159/000259648

Kalaldeh, R., \& Al-Shdaifat, A. (2019). The influence of emphatic/d'/on Modern Standard Arabic vowels: An acoustic analysis. Lingua Posnaniensis, 61(1), 43-61. DOI:10.2478/linpo-2019-0003

Kriba, H. A. (2010). Acoustic parameters of emphasis in Libyan Arabic, (Doctoral dissertation). Newcastle University.

Laufer, A., \& Baer, T. (1988). The emphatic and pharyngeal sounds in Hebrew and in Arabic. Language and Speech, 31(2), 181-205. Available at DOI:10.1177/002383098803100205

Lehn, W. (1963). Emphasis in Cairo Arabic. Language, 39(1), 29-39. Available at https://doi.org/10.2307/410760

McCarus, E. N., \& Yacoub, A. I. (1962). Elements of contemporary Arabic. Ann Arbor Publishers.

McCarthy, J. J. (1994). The phonetics and phonology of Semitic pharyngeals. Papers in Laboratory Phonology III: Phonological Structure and Phonetic Form, 86, 191-233.

McCarthy, J. (2008). Doing optimality theory. Blackwell.

Mielke, J. (2004). The emergence of distinctive features, (Doctoral dissertation). The Ohio State University.

Mustafawi, E. M. (2006). An optimality theoretic approach to variable consonantal alternations in Qatari Arabic, (Doctoral dissertation). University of Ottawa. https://doi.org/doi:10.7282/T3ZP44ZD

Norlin, K. (1987). A phonetic study of emphasis and vowels in Egyptian Arabic Working, (Doctoral dissertation) Lund University, country. Available at

ISSN: 2550-1542 | www.awej-tls.org 
AWEJ for Translation \& Literary Studies Volume, 5 Number 3. August 2021

Oueslati, J. (2017). The phonetic and phonological status of the r-phones in Tunisian Arabic. Lingua Posnaniensis, 59(2), 69-85. DOI:10.1515/linpo-2017-0013

Rose, S. (1996). Variable laryngeals and vowel lowering. Phonology, 13(1), 73-117. doi:10.1017/S0952675700000191

Slimani, K., \& Zhang, J. (2017). Assimilation in the Djelfa dialect of Algerian Arabic: An OT Account. Linguistics and Literature Studies, 5(3), 213-223. 10.13189/1ls.2017.050309.

Turton, D. (2012). The darkening of English/l: A stochastic stratal OT analysis.

Von Denffer, A. (1983). Ulum al-Qur'an [Quran Sciences]. The Islamic Foundation, 41-42.

Youssef, I. (2019). The phonology and micro-typology of Arabic R. Glossa: A journal of general linguistics, 4 (1), 1-36. 